\title{
Post Operative Hyperglycemia-An Under Investigated Disease in West Africa
}

\author{
Jonathan L Ajah* \\ Specialty Registrar in Surgery, Jos University Teaching Hospital, Nigeria
}

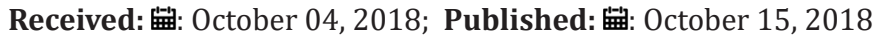

*Corresponding author: Jonathan L Ajah, Specialty Registrar in Surgery, Jos University Teaching Hospital, Nigeria

\section{Introduction}

After surgical operation or trauma, postoperative hyperglycaemia develops as a result of increased glucose production combined with decreased glucose uptake in peripheral tissues [1-2]. This is largely as a result of insulin resistance which is transiently induced within the stressed patient. It has been suggested that mechanisms for this phenomenon include the action of pro-inflammatory cytokines and the decreased responsiveness of insulin-regulated glucose transporter proteins [1-2]. It is also noticed that the degree of insulin resistance is proportional to the magnitude of the injurious process [1-2]. Following routine upper abdominal surgery, insulin resistance may persist for approximately 2 weeks [1]. Clinically postoperative patients with insulin resistance behave in similar manner to individuals with type II diabetes mellitus and are at increased risk of sepsis, deteriorating renal function, polyneuropathy and death [1-2]. The mainstay management of insulin resistance is intravenous insulin infusion. Insulin infusions may be used in either an intensive approach (i.e. sliding scales are manipulated to normalise the blood glucose level) or a conservative approach (i.e. insulin is administered when the blood glucose level exceeds a defined limit and discontinued when the level falls [1].

\section{Background \& Review of Literature}

This mini review was inspired by poor data on the incidence of postoperative hyperglycaemia in non-diabetic patients undergoing elective surgeries in our teaching hospital, Nigeria and West Africa. Since the early nineteenth century postoperative hyperglycaemia has been recognised as a component of the metabolic response to trauma. Current medical knowledge no longer considers it to be benign [3-4]. Interestingly it been extensively studied in several parts of the world with numerous studies on how it affects outcomes of various procedures in different organ-systems [1,5,6]. Paradoxically there is good evidence that postoperative hyperglycaemia is likely to be associated with more adverse morbidity in non-diabetics compared to diabetics [5]. Other investigators have found out that there is significant correlation between the type of surgery and certain preoperative characteristics and the development of postoperative hyperglycaemia [5,7]. Few relevant local studies exist on the subject matter. This justifies the need for a prospective cohort study to determine the incidence of postoperative hyperglycaemia in non-diabetic patients who will undergo surgery as well as statistically determine the relative risk or risk ratio of non-diabetic patients whose end point of care was operative or non-operative.

\section{Diabetes Diagnosis (Figure 1).}

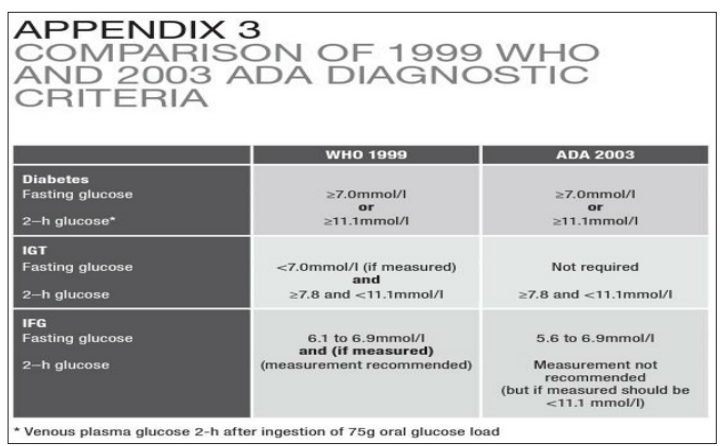

Figure 1: The WHO/IDF versus American Diabetes Association.

\section{References}

1. Azarfarin R, Asl AA (2008) Prevalence and intensity of hyperglycemia in non-diabetic patients undergoing coronary artery bypass graft surgery with and without cardiopulmonary bypass. Saudi Med J 29(9): 12941298.

2. Russell RCG, Williams NS, Bulstrode CJK (2004) Bailey \& Love's Short Practice of Surgery, $24^{\text {th }}$ (Edn.). pp. 146-74.

3. Conner TM, Flesner Gurley KR, Barner JC (2005) Hyperglycemia in the hospital setting: The case for improved control among non-diabetics. Anna Pharmacother 39(3): 492-501.

4. Goyal N, Randeep Kaur, Ambuj Sud, Nilesh Ghorpade, Manu Gupta (2014) Non Diabetic and Stress Induced Hyperglycemia $[\mathrm{SIH}]$ in Orthopaedic 
Practice What do we know so Far? Journal of clinical and diagnostic research 8(10): LH01-LH03.

5. Garg R, Grover A, McGurk S, Rawn JD (2013) Predictors of hyperglycemia after cardiac surgery in nondiabetic patients. Journal of Thoracic and Cardiovascular Surgery 145(4): 1083-1087.

6. Fiorillo C, Rosa F, Quero G, Menghi R, Doglietto GB, et al. (2016) Postoperative hyperglycemia in nondiabetic patients after gastric surgery for cancer: perioperative outcomes. Gastric cancer 20(3): 536542.

ISSN: 2574-1241

DOI: $10.26717 / B J S T R .2018 .10 .001895$

Jonathan L Ajah. Biomed J Sci \& Tech Res

(c) (i) This work is licensed under Creative

Submission Link: https://biomedres.us/submit-manuscript.php
7. Polderman JA, Van Velzen L, Wasmoeth LG, Eshuis JH, Houweling PL, et al. (2015) Hyperglycemia and ambulatory surgery. Minerva Anestesiologica 81(9): 951-959.

8. World Health Organization (2016) Global Report on Diabetes, Isbn 978 p .88.

9. Badoe EA, Archampong EQ, Da Rocha-Afodu JT (2009) Principles and practice of surgery including pathology in the tropics. ( $4^{\text {th }}$ edn.). Ghana. Ghana Publishing Corporation pp. 347-372.

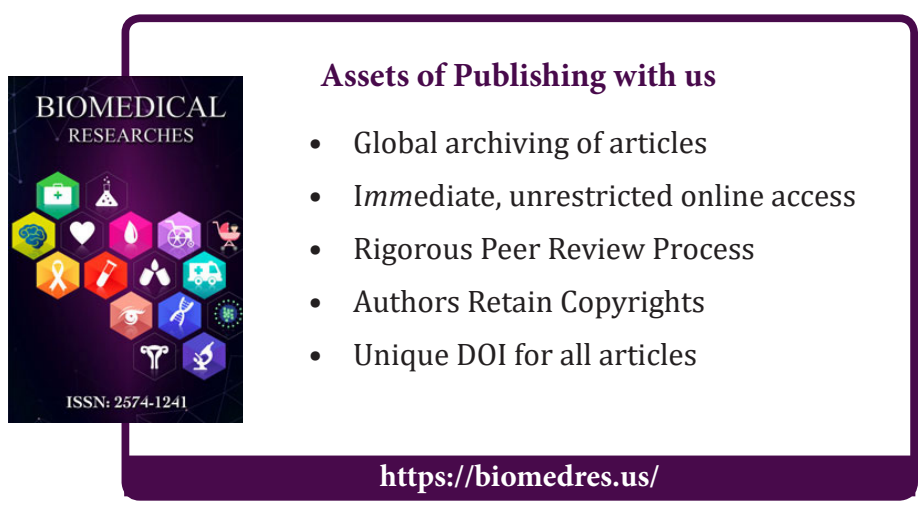

